\title{
SELECTIVITY OF HERBICIDES APPLIED IN POST-EMERGENCE OF SHOWY CROTALARIA ${ }^{1}$
}

\author{
GUILHERME BRAGA PEREIRA BRAZ ${ }^{2 *}$, RUBEM SILVÉRIO DE OLIVEIRA JÚNIOR ${ }^{2}$, JAMIL CONSTANTIN ${ }^{2}$, \\ HUDSON KAGUEYAMA TAKANO ${ }^{2}$, FERNANDA BRUNETTA GODINHO ${ }^{3}$
}

\begin{abstract}
Weed control is essential to reduce or eliminate the interference of weeds on crops. Chemical control with the application of herbicides consists of the most used method, with this aim in grain producing areas. Information about the selectivity of herbicides to C. spectabilis (showy crotalaria) are scarce, which are critical for the management of this species as a crop. One field experiment was performed to evaluate the selectivity of herbicides applied in post-emergence of showy crotalaria. The herbicides bentazon (720 and 576 $\left.\mathrm{g} \mathrm{ha}^{-1}\right)$, imazethapyr (106 and $\left.79.5 \mathrm{~g} \mathrm{ha}^{-1}\right)$, pyrithiobac-sodium $\left(84 \mathrm{~g} \mathrm{ha}^{-1}\right)$, flumiclorac $\left(60 \mathrm{~g} \mathrm{ha}^{-1}\right)$, flumiclorac in sequential application $\left(30 / 30 \mathrm{~g} \mathrm{ha}^{-1}\right)$, imazethapyr + bentazon $\left(106+480 \mathrm{~g} \mathrm{ha}^{-1}\right)$, and clethodim + quizalofop $\left(96+100 \mathrm{~g} \mathrm{ha}^{-1}\right)$ were applied in plants with four true leaves, also using a control without herbicide application. Pyrithiobac-sodium and flumiclorac isolated and the tankmix of imazethapyr + bentazon provided greater injuries to showy crotalaria, also affecting the final plant height. Pyrithiobac-sodium $\left(84 \mathrm{~g} \mathrm{ha}^{-1}\right)$ was not selective to showy crotalaria. The herbicides imazethapyr $\left(79.5 \mathrm{~g} \mathrm{ha}^{-1}\right)$, flumiclorac (sequential application), and bentazon (576 $\mathrm{g} \mathrm{ha}^{-1}$ ), despite the association between clethodim + quizalofop, can be used for weed management in showy crotalaria crop.
\end{abstract}

Keywords: Crotalaria spectabilis. Cover crops. Intoxication by herbicides. Weed management.

\section{SELETIVIDADE DE HERBICIDAS APLICADOS EM PÓS-EMERGÊNCIA DA CROTALÁRIA}

RESUMO - O manejo de plantas daninhas é prática fundamental para reduzir ou eliminar a interferência da comunidade infestante sobre a espécie cultivada. O método de controle químico, por meio da aplicação de herbicidas, consiste no mais utilizado com esta finalidade em áreas de produção de larga escala. Informações de seletividade de herbicidas para C. spectabilis (crotalária) são escassas, sendo estas de suma importância para o manejo desta espécie como cultura. Um experimento de campo foi realizado para avaliar a seletividade de herbicidas aplicados em pós-emergência na crotalária. Os herbicidas bentazon (720 e $\left.576 \mathrm{~g} \mathrm{ha}^{-1}\right)$, imazethapyr (106 e 79,5 $\left.\mathrm{g} \mathrm{ha}^{-1}\right)$, pyrithiobac-sodium $\left(84 \mathrm{~g} \mathrm{ha}^{-1}\right)$, flumiclorac $\left(60 \mathrm{~g} \mathrm{ha}^{-1}\right)$, flumiclorac em aplicação sequencial $\left(30 / 30 \mathrm{~g} \mathrm{ha}^{-1}\right)$, imazethapyr + bentazon $\left(106+480 \mathrm{~g} \mathrm{ha}^{-1}\right)$, clethodim + quizalofop $\left(96+100 \mathrm{~g} \mathrm{ha}^{-1}\right)$ foram aplicados sob plantas com quatro folhas verdadeiras, constando também entre os tratamentos testemunha sem aplicação de herbicidas. Pyrithiobac-sodium e flumiclorac isolados e a mistura entre imazethapyr + bentazon proporcionaram maiores injúrias a crotalária, afetando também a altura final das plantas. O pyrithiobac-sodium $\left(84 \mathrm{~g} \mathrm{ha}^{-1}\right)$ não foi seletivo para a crotalária. Os herbicidas imazethapyr $\left(79,5 \mathrm{~g} \mathrm{ha}^{-1}\right)$, flumiclorac (em aplicação sequencial), bentazon (576 $\left.\mathrm{g} \mathrm{ha}^{-1}\right)$, além da associação entre clethodim + quizalofop podem ser utilizados para o manejo de plantas daninhas na cultura da crotalária.

Palavras-chave: Crotalaria spectabilis. Culturas de cobertura. Intoxicação por herbicidas. Manejo de plantas daninhas.

\footnotetext{
*Corresponding author

${ }^{1}$ Received for publication in $03 / 15 / 2016$; accepted in $05 / 23 / 2016$.

Paper extracted from the doctoral thesis of the first author.

${ }^{2}$ Center for Advanced Studies in Weed Research/Agronomy Departament, Universidade Estadual de Maringá, Maringá, PR, Brazil; guilhermebrag@gmail.com, rubem.oliveirajr@gmail.com, constantin@teracom.com.br, hudsontakano@gmail.com.

${ }^{3}$ Graduate Program in Agronomy/Agronomy Departament, Universidade Estadual de Maringá, Maringá, PR, Brazil; fernandaabg@hotmail.com.
} 


\section{INTRODUCTION}

The change in cropping system of certain plant species, where the same shall be sown in large areas, makes it necessary to perform a greater number of cultural practices, as the increase in acreage provides changes in the interactions between fauna and flora, increasing pressure from pests and diseases due to the highest host offer. Therefore, when a new crop is included, it is also important to carry out studies that aim to create alternatives to the plant protection management of the species.

The plant protection management of a crop corresponds to care with three main biotic factors that affect plant development: disease-causing organisms, insects and invertebrate parasites, and weeds. The weeds cause damage to the crops by a set of actions called interference (GHANIZADEH et al., 2014). The weeds also have the potential to host pests and diseases, demonstrating that these have a wide relation with other biotic factors that compromise plant development (MOURELOS et al., 2014).

Crotalaria spectabilis (showy crotalaria) showed an increase in cultivated area in the central region of Brazil, mainly by the control imposed on different nematodes species, beyond the availability of nitrogen in soil by biological fixation (ROSA et al., 2013). Despite this increase in cultivation, information about the tolerance of this species to the interference imposed by weeds remains scarce. In the literature, is has been reported that some crotalaria species showed great potential for weed suppression, with this effect being attributed mainly to soil shading and the biomass produced (TIMOSSI et al., 2011).

The adoption of strategies aimed at weed control is essential to ensure that weeds do not affect the development of showy crotalaria, in which different methods are used. The chemical control of weeds via herbicide application consists of the most common method used in different crops, and has great efficiency of control when adopted in combination with cultural methods of weed management (RONCHI et al., 2010; HARKER; O'DONOVAN, 2013).

The selectivity is one of the main issues that need to be clarify when positioned a particular herbicide for a crop, once the damages caused by the products may be greater than the interference exerted by weeds. Several factors can influence the selectivity, such as the crop stage development, the plant genetic material and the soil and weather conditions at the application (NORSWORTHY et al., 2012).

Currently, there are no herbicides registered for weed control in areas cultivated with showy crotalaria in Brazil. The lack of interest by the companies in registering herbicides for specific use in showy crotalaria restricts the validation of products for use in this crop, since it is not a crop that has wide economic return, and the cost of registering a molecule is high. Nevertheless, for scientific purposes, some studies already been developed evaluating the tolerance of showy crotalaria to different herbicides. In studies aiming to evaluate the selection of phytoremediator species for herbicides with high residual activity, showy crotalaria showed tolerates low doses of the herbicides trifloxysulfuron-sodium and diclosulan (PROCÓPIO et al., 2004; MONQUERO et al., 2013).

Thus, this study aimed to evaluate the selectivity of herbicides applied in the post-emergence of showy crotalaria (C. spectabilis).

\section{MATERIAL AND METHODS}

The experiment was conducted in the Experimental Farm of Iguatemi belonging to the Universidade Estadual de Maringá, located in Maringá (PR) (2323'59.23''S; 5157'00.79' 'W; 501 $\mathrm{m}$ altitude). The experiment was conducted from $02 / 25 / 2013$ to $05 / 27 / 2013$. According to the Köppen's classification, the climate for the location is Cfa - mesothermal humid subtropical, with hot summers and infrequent frosts, with a tendency towards more concentrated rainfall during summer months, but with no dry season. Figure 1 shows the precipitation and temperature (maximum and minimum) data recorded during the experiment conduction period.

Prior to the experiment installation, soil samples were collected $(20 \mathrm{~cm}$ depth $)$ in the experimental area to carry out the physicochemical analysis, obtaining the following values: $\mathrm{pH}\left(\mathrm{CaCl}_{2}\right)$ 5.9; $1.3 \mathrm{cmol}_{\mathrm{c}} \mathrm{dm}^{-3}$ of $\mathrm{H}^{+}+\mathrm{Al}^{+3} ; 2.1 \mathrm{cmol}_{\mathrm{c}} \mathrm{dm}^{-3}$ of $\mathrm{Ca}^{+2} ; 0.9 \mathrm{cmol}_{\mathrm{c}} \mathrm{dm}^{-3}$ of $\mathrm{Mg}^{+2} ; 0.3 \mathrm{cmol}_{\mathrm{c}} \mathrm{dm}^{-3}$ of $\mathrm{K}^{+}$; $34 \mathrm{mg} \mathrm{dm}^{-3}$ of $\mathrm{P} ; 1.4 \%$ of soil organic matter; $72.5 \%$ of sand; $6 \%$ of silt; and $21.5 \%$ of clay (sandy clay loam texture). The soil was identified as Argissolo Vermelho distrófico (Brazilian Oxisol).

On January 10, 2013, a harrowing operation to eliminate emerged weeds in the area was carried out. Before sowing, the burndown of the area was performed through two herbicide applications, with the first being held ten days before sowing $(02 / 15 / 2016)$, with glyphosate $\left(1440 \mathrm{~g}\right.$ a.i. ha $\left.{ }^{-1}\right)$ application, and the second held on the sowing day $(02 / 25 / 2013)$, using paraquat (400 $\left.\mathrm{g} \mathrm{ha}^{-1}\right)$ with the addition of Agral $^{\circledR} 0.2 \% \mathrm{v} \mathrm{v}^{-1}$ to the spray solution. 


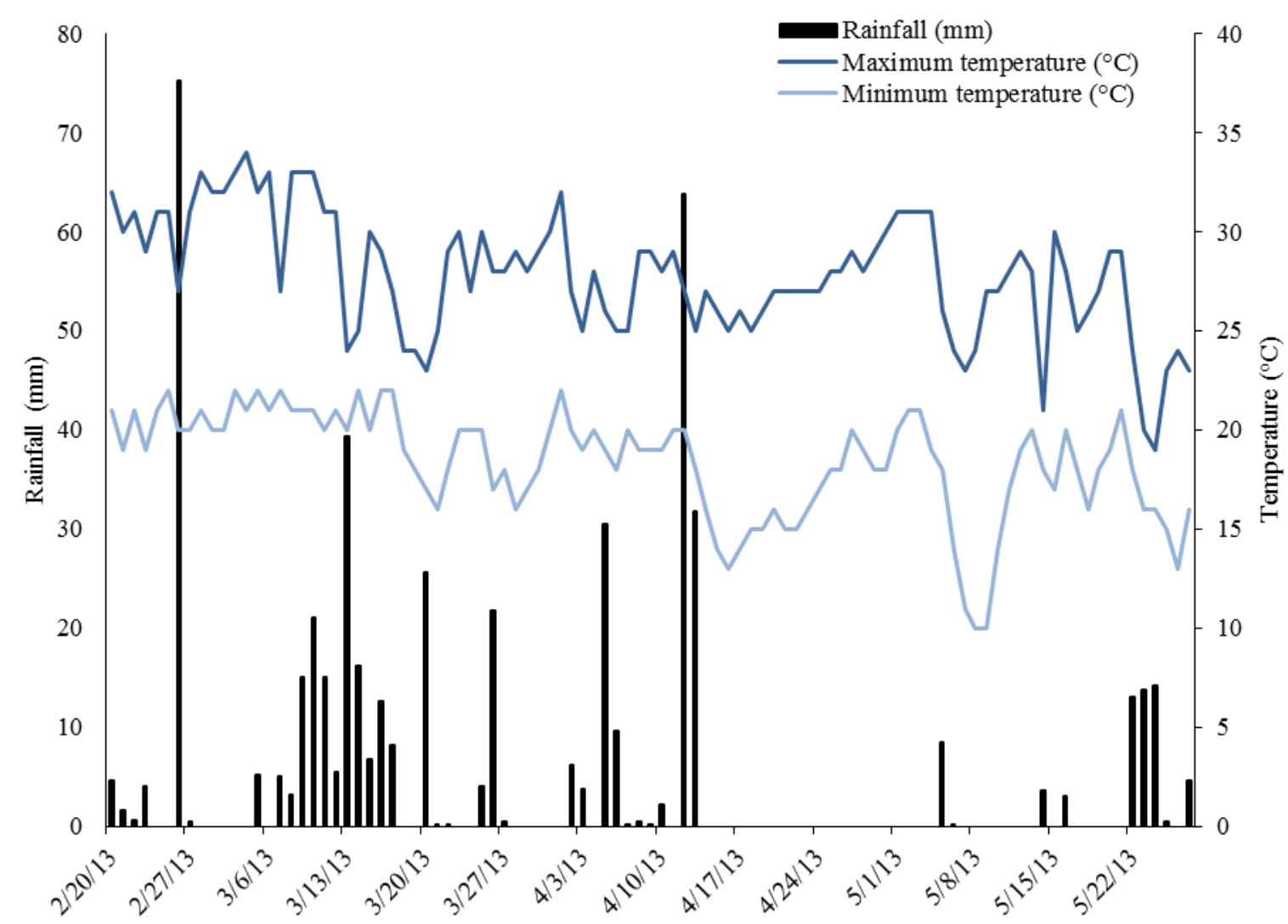

Source: Instituto Nacional de Meteorologia (INMET), Maringá (PR).

Figure 1. Rainfall $(\mathrm{mm})$, maximum and minimum temperature $\left({ }^{\circ} \mathrm{C}\right)$ data during the experiment conduction period about selectivity of post-emergence herbicides to showy crotalaria.

The sowing fertilization consisted of the application of $320 \mathrm{~kg} \mathrm{ha}^{-1}$ of the formulated 8-20-18 (N-P-K) in the furrow. On February 25, 2013, sowing of showy crotalaria was performed using a manual precision seeder, adopting a density of 35 seeds per meter and spacing between rows of $0.45 \mathrm{~m}$, placing the seeds at a depth of $3 \mathrm{~cm}$ from the soil surface. The showy crotalaria seedlings emerged on March 05, 2013 (8 days after sowing).

The statistical design used was the randomized complete block with four repetitions, evaluating ten treatments, which consisted of herbicides and doses that showed potential to be selective to showy crotalaria selected from the work developed by Braz et al. (2015), and a control without herbicide application (Table 1). Each experimental unit was composed of seven rows of showy crotalaria, with a length of $4 \mathrm{~m}$. For the evaluations, $0.5 \mathrm{~m}$ of border from each plot was disregarded, totaling $6.45 \mathrm{~m}^{2}$ of useful area.

Table 1. Treatments evaluated in the experiment of selectivity of post-emergence herbicides to showy crotalaria.

\begin{tabular}{|c|c|}
\hline Treatments & Dose $\left(\mathrm{g} \mathrm{ha}^{-1}\right)$ \\
\hline Bentazon $^{1}$ & 720 \\
\hline Bentazon $^{1}$ & 576 \\
\hline Imazethapyr & 106 \\
\hline Imazethapyr & 79.5 \\
\hline Imazethapyr + bentazon & $106+480$ \\
\hline Flumiclorac $^{2}$ & 60 \\
\hline Flumiclorac $^{2}$ / flumiclorac ${ }^{2}$ & $30 / 30$ \\
\hline Pyrithiobac-sodium ${ }^{3}$ & 84 \\
\hline Clethodim + quizalofop ${ }^{1}$ & $96+100$ \\
\hline Weeded control (without herbicide) & - \\
\hline
\end{tabular}

/Indicates sequential application (10 days interval); + Indicates tankmix; ${ }^{1} \operatorname{Assist}^{\circledR}\left(0.5 \% \mathrm{v} \mathrm{v}^{-1}\right) ;{ }^{2} \operatorname{Assist}^{\circledR}\left(0.2 \% \mathrm{v} \mathrm{v}^{-1}\right)$;

${ }^{3} \operatorname{Iharol}^{\circledR}\left(0.5 \% \mathrm{v} \mathrm{v}^{-1}\right)$. 
The treatment application was carried out on March 22, 2013 (17h55 to 18h45), when the showy crotalaria plants were in the stage of four developed leaves, with a height between 6 to $8 \mathrm{~cm}$. At the time of application, weather conditions were: average temperature $-24^{\circ} \mathrm{C}$; average relative humidity $(\mathrm{RH})-$ $85 \%$; and wind speed $-0.4 \mathrm{~km} \mathrm{~h}^{-1}$, with the soil being moist in all plots. In the treatment of the sequential application of flumiclorac, the second was performed 10 days after the first $(17 \mathrm{~h} 00$ to $17 \mathrm{~h} 15$ on $04 / 01 / 2013$ ), when the showy crotalaria plants had five developed leaves and a height between 10 and $12 \mathrm{~cm}$ (stage of the plants present in the control without herbicide). At the time of this application, the weather conditions were: average temperature $24^{\circ} \mathrm{C}$; average relative humidity $(\mathrm{RH})-75 \%$; and wind speed $-0.8 \mathrm{~km} \mathrm{~h}^{-1}$, with the soil being moist. The applications were performed using a $\mathrm{CO}_{2}$-pressurized backpack sprayer under constant pressure $\left(35 \mathrm{lb} \mathrm{pol}^{-2}\right.$ ) equipped with four XR 110.02 flat-fan tips, providing an application volume of 200 $\mathrm{L} \mathrm{ha}^{-1}$.

All plots were weeded during the entire conduction period of the experiment, to eliminate the effect of weed interference on the showy crotalaria development, leaving the plants exposed only to the effect of herbicides. Furthermore, to achieve the control of certain pests (rattlebox moth - Utetheisa ornatrix) that affected the crop, one insecticide application using spinosad $\left(24 \mathrm{~g} \mathrm{ha}^{-1}\right)$ was performed on April 18, 2013, not adding any adjuvant to the spray solution.

Phytotoxicity evaluations of showy crotalaria were performed at $7,14,21$, and 35 days after the first herbicide application - DAA (24, 31, 38, 45, and 52 days after emergence - DAE), using a visual scale, $0-100 \%$, where $0 \%$ denotes the absence of symptoms and $100 \%$ indicates complete plant death (SBCPD, 1995). Besides that, in the same periods, phytotoxicity evaluations were carried out by adopting visual scale (1-9, with 1 meaning an absence of symptoms and 9 denoting complete plant death), considering only the symptoms observed in young leaves (EWRC, 1964)

At 35 DAA (52 DAE), a stand evaluation was performed, counting the number of showy crotalaria plants present in $4 \mathrm{~m}$. In addition, a plant height assessment was performed at 48 DAA (65 DAE), measuring the height of the plant from the soil level to the point of the last fully expanded leaf, in ten samples per plot. At 48 DAA, light incidence in showy crotalaria inter-rows was evaluated using a lux meter (Minipa, MLM-1011 model), performing two samplings per plot. On the same date, five plants per plot were collected, removing the leaves and counting the number of these per plant, presenting the data as number of leaves per plant. A leaf area evaluation $\left(\mathrm{cm}^{2}\right)$ was also carried out using the material collected for the number of leaves assessment, using an area meter model LI 3100.
Besides these evaluations, at 48 DAA, the shoot fresh mass (five plants per plot), and the leaves dry mass, stem and total shoot were determined, with these data being obtained after drying the plant material in a drying oven with forced air circulation for 72 hours and a mean temperature of $65^{\circ} \mathrm{C}$.

The statistical analysis was performed using the software Sisvar (FERREIRA, 2011). Data were submitted to variance analysis and when a significant treatment effect was obtained, the means were compared using the Scott-Knott test $(p \leq 0.10)$.

\section{RESULTS AND DISCUSSION}

At 7 DAA of the herbicides in the post-emergence of showy crotalaria, it was verified that the application of pyrithiobac-sodium caused higher levels of injuries, shown as intense yellowing, even in the young leaves emitted by the plants (Table 2). In relation to the dose applied, it was observed that for bentazon, imazethapyr and flumiclorac, the addition of active ingredient provided increased symptoms of crop injuries.

An important factor to highlight for the use of bentazon is that the injuries were viewed only in the older leaves (which received the herbicide application). The only treatment that did not promote any injuries to showy crotalaria plants, for any of the phytotoxicity evaluations, was the tankmix of clethodim with quizalofop, as these plants were in visual conditions similar to the control. This tolerance to ACCase inhibitor herbicides by dicotyledons is related to the size difference of the enzyme ACCase that such species have, as the enzyme present in the chloroplast is bigger than that in the cytosol, which increases the capacity to metabolize these herbicides. In monocotyledonous plants, both ACCase enzymes has similar size (HOWARD; RIDLEY, 1990).

In the second phytotoxicity evaluation performed at $14 \mathrm{DAA}$, a reduction/stagnation in the injuries caused by herbicides was verified with contact action (bentazon and flumiclorac), while for the systemic action products (imazethapyr and pyrithiobac-sodium), there was an increase in the intoxication levels of the showy crotalaria plants. The treatment composed of the mixture of bentazon and imazethapyr showed an increase in intoxication symptoms in relation to the first evaluation, with an average increase of $10 \%$ at 14 DAA.

In relation to flumiclorac, in this phytotoxicity evaluation (14 DAA), the importance of dose installment in sequential applications was evident, with the aim of increasing the selectivity of this herbicide. When applied in single doses (flumiclorac - $60 \mathrm{~g} \mathrm{ha}^{-1}$ ), the herbicide caused levels of injuries that were $10 \%$ higher compared to the half dose. In addition to this greater tolerance of showy crotalaria to flumiclorac in sequential 
applications, another benefit is related to the effectiveness of weed management, with evidence to suggest that this product shows better efficacy when applied in this manner, as demonstrated for different sida species (Sida sp.), and Euphorbia heterophylla (OLIVEIRA JR. et al., 2006; CONSTANTIN et al., 2007).

Table 2. Intoxication and stand of plants (1 meter) as a function of the application of post-emergence herbicides in showy crotalaria.

\begin{tabular}{|c|c|c|c|c|c|c|c|c|}
\hline \multirow{2}{*}{ Treatments } & \multirow{2}{*}{$\left(\mathrm{g} \mathrm{ha}^{-1}\right)$} & \multicolumn{7}{|c|}{ Phytotoxicity } \\
\hline & & 7 DAA & & $14 \mathrm{DAA}$ & & \multicolumn{3}{|c|}{$21 \mathrm{DAA}$} \\
\hline Bentazon $^{1}$ & 720 & $1.50^{4}-11.25$ & $\mathrm{~d}$ & $1.00-9.25$ & $\mathrm{e}$ & \multicolumn{3}{|c|}{$1.00-12.00$} \\
\hline Bentazon $^{1}$ & 576 & $1.25-3.75$ & e & $1.00-4.00$ & $\mathrm{f}$ & \multicolumn{2}{|c|}{$1.00-7.50$} & $\mathrm{e}$ \\
\hline Imazethapyr & 106 & $2.75-11.25$ & $\mathrm{~d}$ & $2.75-21.75$ & $\mathrm{c}$ & \multicolumn{2}{|c|}{$1.50-23.00$} & $\mathrm{c}$ \\
\hline Imazethapyr & 79.5 & $2.00-6.25$ & e & $2.00-16.25$ & $\mathrm{~d}$ & \multicolumn{2}{|c|}{$1.25-15.00$} & $\mathrm{~d}$ \\
\hline Imazethapyr + bentazon & $106+480$ & $3.00-17.50$ & $\mathrm{c}$ & $3.00-28.75$ & $\mathrm{~b}$ & \multicolumn{2}{|c|}{$1.00-32.50$} & $\mathrm{~b}$ \\
\hline Flumiclorac $^{2}$ & 60 & $4.00-23.75$ & $\mathrm{~b}$ & $1.00-15.50$ & $\mathrm{~d}$ & \multicolumn{2}{|c|}{$1.00-23.00$} & $\mathrm{c}$ \\
\hline Flumiclorac $^{2}$ / flumiclorac ${ }^{2}$ & $30 / 30$ & $3.00-13.75$ & $\mathrm{~d}$ & $3.25-16.25$ & $\mathrm{~d}$ & \multicolumn{2}{|c|}{$2.00-17.50$} & $\mathrm{~d}$ \\
\hline Pyrithiobac-sodium ${ }^{3}$ & 84 & $3.75-28.75$ & $\mathrm{a}$ & $3.75-44.00$ & $\mathrm{a}$ & \multicolumn{2}{|c|}{$2.00-45.75$} & $\mathrm{a}$ \\
\hline Clethodim + quizalofop $^{1}$ & $96+100$ & $1.00-0.00$ & $\mathrm{f}$ & $1.00-0.00$ & $\mathrm{f}$ & \multicolumn{2}{|c|}{$1.00-0.00$} & $\mathrm{e}$ \\
\hline Control & - & $1.00-0.00$ & $\mathrm{f}$ & $1.00-0.00$ & $\mathrm{f}$ & \multicolumn{2}{|c|}{$1.00-0.00$} & . \\
\hline CV (\%) & & \multicolumn{2}{|l|}{23.03} & \multicolumn{2}{|l|}{29.91} & \multicolumn{2}{|c|}{33.70} & \\
\hline \multirow{2}{*}{ Treatments } & \multirow{2}{*}{$\left(\mathrm{g} \mathrm{ha}^{-1}\right)$} & \multicolumn{4}{|c|}{ Phytotoxicity } & \multirow{2}{*}{\multicolumn{2}{|c|}{ Stand }} & \\
\hline & & \multicolumn{2}{|c|}{$28 \mathrm{DAA}$} & \multicolumn{2}{|l|}{$35 \mathrm{DAA}$} & & & \\
\hline Bentazon $^{1}$ & 720 & $1.00-13.75$ & $\mathrm{~b}$ & $1.00-2.50$ & $\mathrm{~d}$ & 16.18 & $\mathrm{a}$ & \\
\hline Bentazon $^{1}$ & 576 & $1.00-8.75$ & $\mathrm{~b}$ & $1.00-2.00$ & $\mathrm{~d}$ & 16.31 & a & \\
\hline Imazethapyr & 106 & $1.00-15.00$ & $\mathrm{~b}$ & $1.00-11.25$ & $\mathrm{c}$ & 16.68 & $\mathrm{a}$ & \\
\hline Imazethapyr & 79.5 & $1.00-5.00$ & $\mathrm{c}$ & $1.00-4.25$ & $\mathrm{~d}$ & 17.50 & $\mathrm{a}$ & \\
\hline Imazethapyr + bentazon & $106+480$ & $1.00-27.50$ & $\mathrm{a}$ & $1.00-22.50$ & $\mathrm{~b}$ & 14.68 & $\mathrm{a}$ & \\
\hline Flumiclorac $^{2}$ & 60 & $1.00-12.50$ & $\mathrm{~b}$ & $1.00-10.50$ & $\mathrm{c}$ & 13.81 & a & \\
\hline Flumiclorac $^{2}$ / flumiclorac ${ }^{2}$ & $30 / 30$ & $1.00-6.25$ & $\mathrm{c}$ & $1.00-3.75$ & $\mathrm{~d}$ & 17.06 & $\mathrm{a}$ & \\
\hline Pyrithiobac-sodium ${ }^{3}$ & 84 & $1.00-31.25$ & $\mathrm{a}$ & $1.00-31.25$ & $\mathrm{a}$ & 16.87 & $\mathrm{a}$ & \\
\hline Clethodim + quizalofop ${ }^{1}$ & $96+100$ & $1.00-0.00$ & $\mathrm{~d}$ & $1.00-0.00$ & $\mathrm{~d}$ & 17.37 & $\mathrm{a}$ & \\
\hline Control & - & $1.00-0.00$ & $\mathrm{~d}$ & $1.00-0.00$ & $\mathrm{~d}$ & 18.37 & $\mathrm{a}$ & \\
\hline CV (\%) & & 33.26 & & 41.71 & & & 92 & \\
\hline
\end{tabular}

/ Indicates sequential application (10 days interval); + Indicates tankmix; ${ }^{1}$ Assist $^{\circledR}\left(0.5 \% \mathrm{v} \mathrm{v}^{-1}\right) ;{ }^{2}$ Assist $^{\circledR}\left(0.2 \% \mathrm{v} \mathrm{v}^{-1}\right) ;{ }^{3}$ Iharol $^{\circledR}\left(0.5 \% \mathrm{v} \mathrm{v}^{-1}\right) .{ }^{4}$ Phytotoxicity grades for new leaves (EWRC, 1964). Means followed by different letters in columns differ significantly by Scott-Knott test $(\mathrm{p} \leq 0.10)$.

The third phytotoxicity evaluation (21 DAA) was the last in which injuries caused by the herbicides were observed in the young leaves emitted by the showy crotalaria (Table 2). The highest intoxication levels were observed in plants that received the application of pyrithiobac-sodium (84 $\mathrm{g} \mathrm{ha}^{-1}$ ), noticing pronounced yellowing in the leaves, and a size reduction of the plants.

At 28 DAA, the treatments that imposed major injuries to the showy crotalaria plants were pyrithiobac-sodium applied isolated and the mixture of the herbicides imazethapyr + bentazon. Aiming to reduce the phytotoxicity symptoms of these treatments, it is necessary to study different doses, or in the case of the association between herbicides (imazethapyr + bentazon), evaluate different proportions of this mixture.

In the last phytotoxicity evaluation, performed at $35 \mathrm{DAA}$, the results were similar to the previous; it can be seen that the treatments with higher selectivity to this variable were bentazon (both doses), imazethapyr (79.5 $\mathrm{g} \mathrm{ha}^{-1}$ ), flumiclorac (sequential application), and the association between the ACCase inhibitor herbicides. For the plants that received an application of these treatments, there were few symptoms of intoxication.

The herbicides applied in the post-emergence of showy crotalaria did not cause the death of plants, since there was no difference between treatments and the control without herbicide application in the stand assessment (Table 2). This behavior was expected as all of the herbicides tested in this experiment had undergone preliminary evaluation (BRAZ et al., 2015), demonstrating potential for use in the weed management of showy crotalaria.

All herbicides applied in post-emergence, whose control spectrum was dicotyledonous species, influenced the plant height of showy crotalaria (Table 3). The lower values of plant height were recorded in treatments with flumiclorac application at full dose $\left(60 \mathrm{~g} \mathrm{ha}^{-1}\right)$, pyrithiobac-sodium (84 $\mathrm{g}$ $\mathrm{ha}^{-1}$ ), and the association between imazethapyr and bentazon.

The light incidence data demonstrated the effect of herbicides on the canopy of showy crotalaria plants (Table 3). For this variable, lower values indicate lower light incidence on the soil between rows, which is associated with an increased area covered by the leaf architecture. Implicitly, higher values of light incidence compared with those 
recorded in the weeded control demonstrate a greater negative effect of the herbicide in the canopy of showy crotalaria plants treated with herbicides.

Higher values of light incidence between rows were verified by treatments with the application of contact action products (excluding the sequential application of flumiclorac), as well as in the plots in which pyrithiobac-sodium was applied. Despite phytotoxicity evaluations not showing increased levels of injuries caused by bentazon, it was noted that this herbicide changed the plant canopy, since the light passage was superior in these plots. This greater light passage resulting from changes promoted by herbicides in the architecture of showy crotalaria plants will influence the cultural control of weeds, since the shading between rows will be lower, and, consequently, there will be an increased possibility to verify new flows of weed emergence.

Table 3. Plant height $(\mathrm{cm})$, light incidence (lux $\mathrm{cm}^{-2}$ ), number of leaves (per plant) and leaf area ( $\mathrm{cm}^{2}$ per plant) of showy crotalaria as a function of the application of post-emergence herbicides.

\begin{tabular}{|c|c|c|c|c|c|}
\hline Treatments & $\left(\mathrm{g} \mathrm{ha}^{-1}\right)$ & Height & & Light incidenc & \\
\hline Bentazon $^{1}$ & 720 & 43.35 & $\mathrm{c}$ & 225.12 & $\mathrm{a}$ \\
\hline Bentazon $^{1}$ & 576 & 49.08 & $\mathrm{~b}$ & 224.12 & $\mathrm{a}$ \\
\hline Imazethapyr & 106 & 45.72 & c & 180.37 & $\mathrm{~b}$ \\
\hline Imazethapyr & 79.5 & 46.07 & $\mathrm{c}$ & 152.25 & $\mathrm{~b}$ \\
\hline Imazethapyr + bentazon & $106+480$ & 35.52 & $\mathrm{~d}$ & 186.25 & $\mathrm{~b}$ \\
\hline Flumiclorac $^{2}$ & 60 & 37.92 & $\mathrm{~d}$ & 245.00 & a \\
\hline Flumiclorac $^{2} /$ flumiclorac $^{2}$ & $30 / 30$ & 45.75 & $\mathrm{c}$ & 159.87 & $\mathrm{~b}$ \\
\hline Pyrithiobac-sodium ${ }^{3}$ & 84 & 34.65 & $\mathrm{~d}$ & 210.87 & $\mathrm{a}$ \\
\hline Clethodim + quizalofop ${ }^{1}$ & $96+100$ & 54.87 & $\mathrm{a}$ & 141.37 & $\mathrm{~b}$ \\
\hline Control & - & 55.02 & $\mathrm{a}$ & 169.87 & $\mathrm{~b}$ \\
\hline CV (\%) & & 16.62 & & 35.36 & \\
\hline Treatments & $\left(\mathrm{g} \mathrm{ha}^{-1}\right)$ & Number of leave & & Leaf area & \\
\hline Bentazon $^{1}$ & 720 & 20.45 & $\mathrm{~b}$ & 2093.61 & $\mathrm{~b}$ \\
\hline Bentazon $^{1}$ & 576 & 24.95 & $\mathrm{~b}$ & 2350.51 & $\mathrm{~b}$ \\
\hline Imazethapyr & 106 & 35.00 & $\mathrm{a}$ & 2351.07 & $\mathrm{~b}$ \\
\hline Imazethapyr & 79.5 & 36.05 & $\mathrm{a}$ & 2581.81 & $\mathrm{a}$ \\
\hline Imazethapyr + bentazon & $106+480$ & 33.40 & $\mathrm{a}$ & 2163.49 & $\mathrm{~b}$ \\
\hline Flumiclorac $^{2}$ & 60 & 24.35 & $\mathrm{~b}$ & 2195.59 & $\mathrm{~b}$ \\
\hline Flumiclorac $^{2} /$ flumiclorac $^{2}$ & $30 / 30$ & 26.20 & $\mathrm{~b}$ & 2358.09 & $\mathrm{~b}$ \\
\hline Pyrithiobac-sodium ${ }^{3}$ & 84 & 24.80 & $\mathrm{~b}$ & 1749.60 & $\mathrm{~b}$ \\
\hline Clethodim + quizalofop ${ }^{1}$ & $96+100$ & 25.60 & $\mathrm{~b}$ & 2804.98 & $\mathrm{a}$ \\
\hline Control & - & 25.50 & $\mathrm{~b}$ & 3060.62 & $\mathrm{a}$ \\
\hline CV (\%) & & 47.23 & & 21.06 & \\
\hline
\end{tabular}

/ Indicates sequential application (10 days interval); + Indicates tankmix; ${ }^{1} \operatorname{Assist}^{\circledR}\left(0.5 \% \mathrm{v} \mathrm{v}^{-1}\right) ;{ }^{2} \operatorname{Assist}^{\circledR}\left(0.2 \% \mathrm{v} \mathrm{v}^{-1}\right)$;

${ }^{3} \mathrm{Iharol}^{\mathbb{R}}\left(0.5 \% \mathrm{v} \mathrm{v}^{-1}\right)$. Means followed by different letters in columns differ significantly by Scott-Knott test $(\mathrm{p} \leq 0.10)$.

Regarding the number of leaves per plant, in all treatments that had the herbicide imazethapyr in their composition, the plants had an increased number of leaves (Table 3 ). The other herbicides did not affect this variable, verifying similar numbers of leaves per plant of the control without herbicide.

The application of post-emergence herbicide influenced the leaf area of showy crotalaria plants, since in seven of the nine treatments evaluated this variable was negatively affected. Only imazethapyr, when applied at a lower dose and the association between ACCase inhibitors did not affect the leaf area of showy crotalaria plants, with values that were similar to those reported for the control without herbicide (Table 3)

By correlating the number of leaves and leaf area data, it was observed that in treatments using imazethapyr, the plants had an increased number of leaves, which implies the possibility of observing an increase in leaf area; however, this did not occur. By dividing the data of leaf area by the number of leaves per plant registered in the weeded control, the result was approximately $120 \mathrm{~cm}^{2}$ per leaf, and the average of the three treatments with imazethapyr gave a result of $67 \mathrm{~cm}^{2}$.

As for the final plant height, herbicides with the spectrum control of dicotyledonous species also affected the fresh and dry biomass accumulation of showy crotalaria plants, with all reporting lower values compared to the control without herbicide (Table 4). The association between clethodim and quizalofop did not affect these variables, demonstrating this to be selective for use in the weed management of monocots, as it interferes in showy crotalaria crop. Among the four variables related to biomass accumulation by the showy crotalaria plants, only the leaves dry biomass differed significantly from the others, and it may be noted that the higher values were viewed in plants that did not receive herbicides. Nevertheless, the plants subjected to the application of the mixture of ACCase inhibitors showed higher values for dry leaves biomass compared to those treated with other herbicides.

As it is sown as a cover crop, reductions in shoot biomass produced by showy crotalaria plants 
are not desirable, since this plant material brings benefits for the rotation system to which the species is inserted. The largest amount of biomass implicates gains for soil organic matter, the increased availability of nutrients extracted by showy crotalaria, beyond the allelopathic effect on weeds and other species that are present in the crop areas (TIMOSSI et al., 2011; SORATTO et al., 2012).

One of the actions carried out by weeds in the interference process is the competition for resources necessary for plant growth and development, with reductions in crop dry biomass being commonly observed as an effect of this action.

An example can be given from work performed with the sorghum crop, verifying dry biomass accumulation that was $41.8 \%$ lower in plants that developed throughout the entire cycle over weed interference compared to those with free coexistence (RODRIGUES et al., 2010).

Table 4. Accumulation of fresh and dry biomass ( $\mathrm{g}$ ) per plant of showy crotalaria subject to the application of post-emergence herbicides.

\begin{tabular}{|c|c|c|c|c|c|}
\hline Treatments & $\left(\mathrm{g} \mathrm{ha}^{-1}\right)$ & \multicolumn{2}{|l|}{ Fresh biomass } & \multicolumn{2}{|l|}{ Dry biomass } \\
\hline Bentazon $^{1}$ & 720 & 94.01 & $\mathrm{~b}$ & 15.88 & $\mathrm{~b}$ \\
\hline Bentazon $^{1}$ & 576 & 119.54 & $\mathrm{~b}$ & 18.85 & $\mathrm{~b}$ \\
\hline Imazethapyr & 106 & 101.13 & $\mathrm{~b}$ & 16.86 & $\mathrm{~b}$ \\
\hline Imazethapyr & 79.5 & 122.64 & $\mathrm{~b}$ & 20.20 & $\mathrm{~b}$ \\
\hline Imazethapyr + bentazon & $106+480$ & 99.06 & $\mathrm{~b}$ & 16.95 & $\mathrm{~b}$ \\
\hline Flumiclorac $^{2}$ & 60 & 99.05 & $\mathrm{~b}$ & 17.15 & $\mathrm{~b}$ \\
\hline Flumiclorac ${ }^{2}$ / flumiclorac ${ }^{2}$ & $30 / 30$ & 114.89 & $\mathrm{~b}$ & 19.18 & $\mathrm{~b}$ \\
\hline Pyrithiobac-sodium ${ }^{3}$ & 84 & 80.85 & $\mathrm{~b}$ & 13.42 & $\mathrm{~b}$ \\
\hline Clethodim + quizalofop $^{1}$ & $96+100$ & 144.80 & $\mathrm{a}$ & 23.53 & a \\
\hline Control & - & 161.59 & $\mathrm{a}$ & 28.70 & $\mathrm{a}$ \\
\hline CV (\%) & & \multicolumn{2}{|l|}{30.42} & \multicolumn{2}{|l|}{24.04} \\
\hline Treatments & $\left(\mathrm{g} \mathrm{ha}^{-1}\right)$ & \multicolumn{2}{|c|}{ Stem dry biomass } & \multicolumn{2}{|c|}{ Leaves dry biomass } \\
\hline Bentazon $^{1}$ & 720 & 5.00 & $\mathrm{~b}$ & 10.88 & $\mathrm{c}$ \\
\hline Bentazon $^{1}$ & 576 & 6.95 & $\mathrm{~b}$ & 11.90 & $\mathrm{c}$ \\
\hline Imazethapyr & 106 & 7.35 & $\mathrm{~b}$ & 9.51 & $\mathrm{c}$ \\
\hline Imazethapyr & 79.5 & 7.42 & $\mathrm{~b}$ & 12.78 & $\mathrm{c}$ \\
\hline Imazethapyr + bentazon & $106+480$ & 5.41 & $\mathrm{~b}$ & 11.54 & $\mathrm{c}$ \\
\hline Flumiclorac $^{2}$ & 60 & 5.39 & $\mathrm{~b}$ & 11.76 & $\mathrm{c}$ \\
\hline Flumiclorac ${ }^{2}$ / flumiclorac ${ }^{2}$ & $30 / 30$ & 7.17 & $\mathrm{~b}$ & 12.00 & $\mathrm{c}$ \\
\hline Pyrithiobac-sodium ${ }^{3}$ & 84 & 4.36 & $\mathrm{~b}$ & 9.06 & $\mathrm{c}$ \\
\hline Clethodim + quizalofop ${ }^{1}$ & $96+100$ & 9.25 & $\mathrm{a}$ & 14.28 & $\mathrm{~b}$ \\
\hline Control & - & 10.57 & $\mathrm{a}$ & 18.13 & $\mathrm{a}$ \\
\hline CV (\%) & & 33.93 & & 23.07 & \\
\hline
\end{tabular}

/ Indicates sequential application (10 days interval); + Indicates tankmix; ${ }^{1}$ Assist ${ }^{\circledR}\left(0.5 \% \mathrm{v} \mathrm{v}^{-1}\right) ;{ }^{2}$ Assist $^{\circledR}\left(0.2 \% \mathrm{v} \mathrm{v}^{-1}\right) ;{ }^{3}$ Iharol $^{\circledR}\left(0.5 \% \mathrm{v} \mathrm{v}^{-1}\right)$. Means followed by different letters in columns differ significantly by Scott-Knott test $(\mathrm{p} \leq 0.10)$.

Such data demonstrate the potential of the weed in reducing the crop development, noting that despite the herbicides applied in post-emergence (control spectrum are the dicotyledonous species) causing reductions in the dry biomass of showy crotalaria plants, these are still lower than those from the weed competition. Moreover, with herbicide use, the main benefit is the minimizing/eliminating weeds.

In summary, beyond the results obtained in the statistical analysis, $20 \%$ of the value of the variables-response observed in the weeded control was adopted, in which treatments that have provided superior changes to this percentage were considered non-selective (Table 5). In general, herbicides that exhibit a control spectrum of dicotyledonous weeds (broadleaf species) affected more variables in comparison with the treatment that applied herbicides with a control focused more on monocot species (association between clethodim + quizalofop).

The imazethapyr applied at a dose of $79.5 \mathrm{~g}$ $\mathrm{ha}^{-1}$ was the most selective treatment for showy crotalaria (excluding clethodim + quizalofop), affecting just one in eight variables-response evaluated. Besides this, flumiclorac in sequential applications $\left(30 / 30 \mathrm{~g} \mathrm{ha}^{-1}\right)$ and imazethapyr in the higher dose $\left(106 \mathrm{~g} \mathrm{ha}^{-1}\right)$ consisted of the second group of latifolicide treatments that affected a lower number of variables-response, being selective for $75 \%$ of these. Another treatment that deserves to be highlighted is bentazon (both doses applied), which was shown to be selective for five of the eight variables-responses.

The herbicides flumiclorac $\left(60 \mathrm{~g} \mathrm{ha}^{-1}\right)$ and pyrithiobac-sodium $\left(84 \mathrm{~g} \mathrm{ha}^{-1}\right)$ in isolated applications, and the association between imazethapyr and bentazon $\left(106+480 \mathrm{~g} \mathrm{ha}^{-1}\right)$, showed little selectivity for showy crotalaria and affected at least $50 \%$ of the variables-responses evaluated. For these herbicides, it is essential to study other doses or different modalities of application (e.g. sequential), aiming to seek selectivity and use these products in the weed 
management of showy crotalaria. An example of this can be given to pyrithiobac-sodium, since it has been used at lower doses $\left(42 \mathrm{~g} \mathrm{ha}^{-1}\right)$ in some farms in
Mato Grosso state, with the aim of controlling volunteer plants of soybeans in showy crotalaria fields.

Table 5. Summary of treatments effect on the variables evaluated in the experiment of herbicide selectivity applied in post-emergence of showy crotalaria.

\begin{tabular}{|c|c|c|c|c|c|c|c|c|}
\hline \multirow{2}{*}{ Treatments $\left(\mathrm{g} \mathrm{ha}^{-1}\right)$} & \multicolumn{2}{|c|}{ Phyto (DAA) ${ }^{4}$} & \multirow{2}{*}{ STA } & \multirow{2}{*}{ HEI } & \multirow{2}{*}{ LI } & \multirow{2}{*}{ NL } & \multirow{2}{*}{ LA } & \multirow{2}{*}{ SDB } \\
\hline & 7 & 35 & & & & & & \\
\hline Bentazon $^{1}(720)$ & $\mathrm{S}^{5}$ & $\mathrm{~S}$ & $\mathrm{~S}$ & $\mathrm{~S}$ & NS & $\mathrm{S}$ & NS & NS \\
\hline Bentazon $^{1}(576)$ & $\mathrm{S}$ & S & S & $\mathrm{S}$ & NS & S & NS & NS \\
\hline Imazethapyr (106) & $\mathrm{S}$ & $\mathrm{S}$ & $\mathrm{S}$ & $\mathrm{S}$ & S & S & NS & NS \\
\hline Imazethapyr (79.5) & $\mathrm{S}$ & S & $\mathrm{S}$ & $\mathrm{S}$ & S & $\mathrm{S}$ & $\mathrm{S}$ & NS \\
\hline Imazethapyr + bentazon $(106+480)$ & $\mathrm{S}$ & NS & $\mathrm{S}$ & NS & $\mathrm{S}$ & $\mathrm{S}$ & NS & NS \\
\hline Flumiclorac $^{2}(60)$ & NS & $\mathrm{S}$ & $\mathrm{S}$ & NS & NS & $\mathrm{S}$ & NS & NS \\
\hline Flumiclorac $^{2}$ / flumiclorac ${ }^{2}(30 / 30)$ & $\mathrm{S}$ & $\mathrm{S}$ & $\mathrm{S}$ & $\mathrm{S}$ & $\mathrm{S}$ & $\mathrm{S}$ & NS & NS \\
\hline Pyrithiobac-sodium ${ }^{3}(84)$ & NS & NS & $\mathrm{S}$ & NS & NS & $\mathrm{S}$ & NS & NS \\
\hline Clethodim + quizalofop $^{1}(96+100)$ & $\mathrm{S}$ & $\mathrm{S}$ & $\mathrm{S}$ & $\mathrm{S}$ & $\mathrm{S}$ & S & $\mathrm{S}$ & S \\
\hline
\end{tabular}

/ Indicates sequential application (10 days interval); + Indicates tankmix; ${ }^{1}$ Assist ${ }^{\circledR}\left(0.5 \% \mathrm{v} \mathrm{v}^{-1}\right) ;{ }^{2} \operatorname{Assist}^{\circledR}\left(0.2 \% \mathrm{v} \mathrm{v}^{-1}\right) ;{ }^{3}$ Iharol $^{\circledR}\left(0.5 \% \mathrm{v} \mathrm{v}^{-1}\right) .{ }^{4}$ Phyto (DAA) - Phytotoxicity; STA - Number of plants; HEI - Plant height; LI - Light incidence; NL - Number of leaves; LA - Leaf area; SDB - Shoot dry biomass. ${ }^{5}$ S - Selective for the evaluated variable; NS Nonselective for the evaluated variable

Even the treatments that affected a lower number of variables-responses caused reductions in shoot dry biomass, demonstrating that the use of these herbicides may compromise the production of biomass by the showy crotalaria plants. Given that there are currently no herbicides registered for use in showy crotalaria crop in Brazil, it is likely that imazethapyr (79.5 $\left.\mathrm{g} \mathrm{ha}^{-1}\right)$, bentazon (576 $\mathrm{g} \mathrm{ha}^{-1}$ ), flumiclorac (sequential application), and the association between clethodim + quizalofop can be used in post-emergence with the aim to control weeds. It is noteworthy that for areas producing seeds of showy crotalaria, it is necessary to assess whether these herbicides affect the production of these (amount), as well as factors related to the quality (germination and vigor).

\section{CONCLUSIONS}

Isolated pyrithiobac-sodium and flumiclorac and the tankmix of imazethapyr + bentazon provided increased injuries to showy crotalaria, also affecting the final plant height.

Pyrithiobac-sodium, when applied post-emergence at a dose of $84 \mathrm{~g} \mathrm{ha}^{-1}$, was not selective for showy crotalaria. The herbicides applied in post-emergence imazethapyr (79.5 g $\mathrm{ha}^{-1}$ ), bentazon (576 $\left.\mathrm{g} \mathrm{ha}^{-1}\right)$, flumiclorac (sequential application - 30/30 $\mathrm{g} \mathrm{ha}^{-1}$ ), and the tankmix of clethodium + quizalofop, can be used for weed management in showy crotalaria crops $(C$. spectabilis).

\section{ACKNOWLEDGEMENTS}

Acknowledgements to $\mathrm{CNPq}$ (Conselho Nacional de Desenvolvimento Científico e
Tecnológico) by the granted financial resources that allowed the development of the present work.

\section{REFERENCES}

BRAZ, G. B. P. et al. Selection of herbicides targeting the use in crop systems cultivated with showy crotalaria. Planta Daninha, Viçosa, v. 33, n. 3, p. 521-534, 2015.

CONSTANTIN, J. et al. Controle de diferentes espécies de guanxuma com aplicações sequenciais de flumiclorac-pentil. Acta Scientiarum. Agronomy, Maringá, v. 29, n. 4, p. 475-480, 2007.

EWRC (European Weed Research Council). Report of $3^{\text {rd }}$ and $4^{\text {th }}$ meetings of EWRC - Committee of Methods in Weed Research. Weed Research, Oxford, v. 4, n. 1, p. 88, 1964.

FERREIRA, D. F. Sisvar: a computer statistical analysis system. Ciência e Agrotecnologia, Lavras, v. 35 , n. 6 , p. 1039-1042, 2011.

GHANIZADEH, H.; LORZADEH, S.; ARYANNIA, N. Effect of weed interference on Zea mays: Growth analysis. Weed Biology and Management, Kyoto, v. 14, n. 2, p. 133-137, 2014.

HARKER, K. N.; O'DONOVAN, J. T. Recent weed control, weed management, and integrated weed management. Weed Technology, Champaign, v. 27, n. 1, p. 1-11, 2013.

HOWARD, J. L.; RIDLEY, S. M. Acetyl-CoA carboxylase: a rapid novel assay procedure used in conjunction with the preparation of enzyme from maize leaves. FEBS Letters, Heidelberg, v. 261, 
n. 2, p. 261-264, 1990.

MONQUERO, P. A. et al. Seleção de espécies de adubos verdes visando à fitorremediação de diclosulam. Planta Daninha, Viçosa, v. 31, n. 1, p. $127-135,2013$.

MOURELOS, C. A. et al. Gramineous and non-gramineous weed species as alternative hosts of Fusarium graminearum, causal agent of Fusarium head blight of wheat, in Argentina. Crop Protection, Guildford, v. 65, n. 1, p. 100-104, 2014.

NORSWORTHY, J. K. et al. Reducing the risks of herbicide resistance: best management practices and recommendations. Weed Science, Champaign, v. 60, n. 1, p. 31-62, 2012.

OLIVEIRA JR., R. S. et al. Aplicações sequenciais de flumiclorac-pentil para o controle de Euphorbia heterophylla na cultura da soja. Acta Scientiarum. Agronomy, Maringá, v. 28, n. 1, p. 115-122, 2006.

PROCÓPIO, S. O. et al. Seleção de plantas com potencial para fitorremediação de solos contaminados com herbicida trifloxysulfuron sodium. Planta Daninha, Viçosa, v. 22, n. 2, p. 315-322, 2004.

RODRIGUES, A. C. P. et al. Períodos de interferência de plantas daninhas na cultura do sorgo. Planta Daninha, Viçosa, v. 28, n. 1, p. 23-31, 2010.

RONCHI, C. P. et al. Manejo de plantas daninhas na cultura do tomateiro. Planta Daninha, Viçosa, v. 28, n. 1, p. 215-228, 2010.

ROSA, J. M. O.; WESTERICH, J. N.; WILCKEN, S. R. S. Reprodução de Meloidogyne javanica em olerícolas e em plantas utilizadas na adubação verde. Tropical Plant Pathology, Brasília, v. 38, n. 2, p. 133-141, 2013.

SOCIEDADE BRASILEIRA DA CIÊNCIA DAS PLANTAS DANINHAS - SBCPD. Procedimentos para instalação, avaliação e análise de experimentos com herbicidas. 1. ed. Londrina, PR: SBCPD, 1995. $42 \mathrm{p}$.

SORATTO, R. P. et al. Produção, decomposição e ciclagem de nutrientes em resíduos de crotalária e milheto, cultivados solteiros e consorciados. Pesquisa Agropecuária Brasileira, Brasília, v. 47, n. 10 , p. $1462-1470,2012$.

TIMOSSI, P. C. et al. Supressão de plantas daninhas e produção de sementes de crotalária, em função de métodos de semeadura. Pesquisa Agropecuária Tropical, Goiânia, v. 41, n. 4, p. 525-530, 2011. 